\title{
Playful strategies in the pediatric hospitalization scenario
}

\author{
Estratégias lúdicas no cenário da hospitalização pediátrica \\ Estrategias lúdicas en el ámbito de la hospitalización pediátrica
}

Received: 04/04/2021 | Reviewed: 04/13/2021 | Accept: 04/14/2021 | Published: 04/25/2021

Mariana Silva Souza

ORCID: https://orcid.org/0000-0003-1920-5367

Christus Faculdade do Piauí, Brazil

E-mail: marianasouza_s@hotmail.com

Daniel Lopes Araújo

ORCID: https://orcid.org/0000-0002-1625-0368

Universidade Federal de Pernambuco, Brazil

E-mail: araujodanielopes@gmail.com

Bruno Abilio da Silva Machado

ORCID: https://orcid.org/0000-0003-1759-0206

Centro Universitário Maurício de Nassau Teresina, Brazil E-mail: brunnoabillio92@gmail.com

Erik Bernardes Moreira Alves

ORCID: https://orcid.org/0000-0002-1005-9482

Centro Universitário de Goiatuba, Brazil

E-mail: erikbernardes.moreira11@gmail.com

Igor Mendes Mendonça

ORCID: https://orcid.org/0000-0001-8983-4738

Centro Universitário de Goiatuba, Brazil

E-mail: igormendesmendonca@gmail.com

Cícero Santos Souza

ORCID: https://orcid.org/0000-0001-5715-3583

Universidade Estadual do Sudoeste da Bahia, Brazil

E-mail: cicerossz@hotmail.com

José Eufrazino Júnior

ORCID: https://orcid.org/0000-0002-4093-7952

Christus Faculdade do Piauí, Brazil

E-mail: eufrazinojunior@gmail.com

José Marcos Fernandes Mascarenhas

ORCID: https://orcid.org/0000-0002-2604-4330

Christus Faculdade do Piauí, Brazil

E-mail: zemarcosmascarenhas@gmail.com

Kayco Damasceno Pereira

ORCID: https://orcid.org/0000-0002-3112-1193

Christus Faculdade do Piauí, Brazil

E-mail: kaycopereir@gmail.com

Getulivan Alcantara de Melo

ORCID: https://orcid.org/0000-0001-9310-2046 Christus Faculdade do Piauí, Brazil

E-mail: getulivan01@gmail.com

Maria Clara Souza Oliveira

ORCID: https://orcid.org/0000-0002-2179-3439 Christus Faculdade do Piauí, Brazil

E-mail: souza.claram09@gmail.com

Carla Michele Silva Ferreira

ORCID: https://orcid.org/0000-0002-7412-9291 Christus Faculdade do Piauí, Brazil

E-mail: carlamichele47@gmail.com

Danielle dos Santos Araujo

ORCID: https://orcid.org/0000-0002-2387-0207 Centro Universitário do Piauí, Brazil

E-mail: dannyswan2011@ @otmail.com

Leandro Luiz da Silva Loures

ORCID: https://orcid.org/0000-0001-8863-8858

Universidade Federal de Juiz de Fora, Brazil

E-mail: leandrolouresnutri@gmail.com

Miguel Felix de Souza Neto

ORCID: https://orcid.org/0000-0003-1666-5413

Universidade Federal do Piauí, Brazil

E-mail: miguelfelixvet@gmail.com 


\author{
Graziele Ferreira Nunes \\ ORCID: https://orcid.org/0000-0001-5298-3692 \\ Faculdade Pitágoras de São Luís, Brazil \\ E-mail: grazielefnunes@hotmail.com \\ Josué Brito Gondim \\ ORCID: https://orcid.org/0000-0002-8888-0932 \\ Instituto Michelle Sales, Brazil \\ E-mail: josue5brito1@gmail.com \\ Millena Raimunda Martins de Almeida Carvalho \\ ORCID: https://orcid.org/0000-0003-2431-2431 \\ Universidade Federal do Piauí, Brazil \\ E-mail: millenamartinsalmeida2@gmail.com \\ Marcos Van Basten do Nascimento Páiva \\ ORCID: https://orcid.org/0000-0003-0730-6742 \\ Christus Faculdade do Piauí, Brazil \\ E-mail: marcosvbasten01@gmail.com \\ Luana Nayra Coutinho de Meneses \\ ORCID: https://orcid.org/0000-0001-6380-0441 \\ Christus Faculdade do Piauí, Brazil \\ E-mail: luananayra5@gmail.com
}

\begin{abstract}
Childhood is a phase of life that, for the most part, is symbolized by the act of playing. It is through this stage that the child has new skills, experiences, and discoveries. In addition, one can also notice the development of processes such as creativity, self-confidence, social-affective relationships, and cognition. However, some situations sometimes hinder the realization of processes that are essential for childhood, hospitalization being one of them. The study aims to know the playful strategies in the scenario of pediatric hospitalization, highlighting its benefits and importance in hospital humanization. This is an integrative review, carried out from articles collected from the Scielo, PubMed, Lilacs, Medline and BDENF databases. The descriptors applied were "Child Health" AND "Play Therapy". The findings showed that play strategies are extremely important in the humanization of care for hospitalized children, as they reduce suffering and make hospitalization less painful and traumatic. It was concluded that playful strategies when implemented in the pediatric hospital setting promote a less traumatic recovery, in addition to allowing for greater tranquility in the hospital environment. Moreover, the use of playful strategies was pointed out by the studies as a communication resource that benefits not only the physical, emotional, and immunological stimuli, but also the relationship between the child and the health professional, thus contributing to a greater trust in the therapy adopted and in the multiprofessional team.
\end{abstract}

Keywords: Child health; Play therapy; Hospitalization.

\title{
Resumo
}

A infância é uma fase da vida que, em sua maior parte, é simbolizada pelo ato de brincar. É por meio dessa etapa que a criança têm novas habilidades, experiências e descobertas. Além disso, percebe-se também o desenvolvimento de processos como criatividade, autoconfiança, relações socio-afetivas e cognição. Contudo, algumas situações, por vezes, dificultam a realização de processos essenciais para a infância, sendo a hospitalização uma delas. $\mathrm{O}$ estudo tem como objetivo conhecer as estratégias lúdicas no cenário da hospitalização pediátrica, evidenciando os seus benefícios e a importância na humanização hospitalar. Trata-se de uma revisão integrativa, realizada a partir de artigos coletados das bases de dados Scielo, PubMed, Lilacs, Medline and BDENF. Os descritores aplicados foram "Child Health" AND "Play Therapy". Os achados mostraram que as estratégias lúdicas são de extrema importância na humanização do cuidar à criança hospitalizada, pois diminuem o sofrimento e permitem que a internação seja menos dolorosa e traumática. Concluiu-se que as estratégias lúdicas quando implementadas no cenário da hospitalização pediátrica promovem uma recuperação menos traumática, além de permitirem uma maior tranquilidade no ambiente hospitalar. Além disso, a utilização das estratégias lúdicas foram apontadas pelos estudos como um recurso de comunicação que beneficia não só os estímulos físicos, emocionais e imunológicos, como também a relação criança e profissional de saúde, assim, contribuindo para uma maior confiança na terapêutica adotada e na equipe multiprofissional.

Palavras-chave: Saúde da criança; Ludoterapia; Hospitalização.

\section{Resumen}

La infancia es una fase de la vida que, en su mayor parte, está simbolizada por el acto de jugar. Es a través de esta etapa que el niño tiene nuevas habilidades, experiencias y descubrimientos. Además, también se percibe el desarrollo de procesos como la creatividad, la autoconfianza, las relaciones socioafectivas y la cognición. Sin embargo, algunas situaciones dificultan a veces la realización de procesos esenciales para la infancia, siendo la hospitalización una de ellas. El estudio tiene como objetivo conocer las estrategias lúdicas en el ámbito de la hospitalización pediátrica, evidenciando sus beneficios y su importancia en la humanización hospitalaria. Se trata de una revisión integradora, 
realizada a partir de artículos recogidos en las bases de datos Scielo, PubMed, Lilacs, Medline y BDENF. Los descriptores aplicados fueron "Salud infantil" Y "Juegaterapia". Los resultados muestran que las estrategias lúdicas son de extrema importancia en la humanización del cuidado de los niños hospitalizados, ya que disminuyen el sufrimiento y permiten que la internación sea menos dolorosa y traumática. Se concluyó que las estrategias lúdicas cuando se implementan en el entorno hospitalario pediátrico promueven una recuperación menos traumática, además de permitir una mayor tranquilidad en el entorno hospitalario. Además, el uso de estrategias lúdicas fue indicado por los estudios como un recurso de comunicación que beneficia no sólo los estímulos físicos, emocionales e inmunológicos, sino también la relación entre el niño y el profesional de la salud, contribuyendo así a una mayor confianza en la terapia adoptada y en el equipo multiprofesional.

Palabras clave: Salud infantil; Terapia de juego; Hospitalización.

\section{Introduction}

Childhood is a phase of life that, for the most part, is symbolized by the act of playing. It is through this stage that the child has new skills, experiences, and discoveries. In addition, it is also perceived the development of processes such as creativity, self-confidence, socio-affective relationships and cognition (Paixão, Damasceno \& Silva, 2016).

However, some situations sometimes hinder the realization of these essential processes for childhood, hospitalization being one of them. It is understood that hospitalization is a remarkable process in any life cycle, especially for a child, who may be isolated depending on his clinical condition (de Oliveira Silva et al., 2019).

With this, in playful activities, understood as those that have the purpose of playing and psychosocial development, the child ends up experiencing new sensations, create new everyday situations, and discover a world different from the usual one. In addition, they can transform children's desires and minimize the discomforts arising from hospitalization, thus assisting in coping with the disease (Lima \& Santos, 2015).

It is also noteworthy that one of the situations that can lead not only the isolation of children, but also social restrictions is childhood cancer, because it is a condition that requires several moments of hospitalization. Thus, the child needs to leave his home and the interaction with his loved ones to adapt to the hospital environment and everything around him (Bezerra et al., 2021).

From this perspective, it is of utmost importance that there is a team trained to deal with such processes in the pediatric hospitalization scenario. The team can implement actions that contribute to the adaptation of the child in this environment, in addition to inserting family members in daily care and decision-making, because studies show that the presence and participation of the family can assist in the care of the hospitalized child, as well as provide more interaction with the team (Dal'bosco et al., 2019).

Therefore, this study aims to know the playful strategies in the scenario of pediatric hospitalization, highlighting its benefits and importance in hospital humanization.

\section{Methodology}

The study is an integrative literature review, qualitative in nature. This type of review is one of the analytical methods of relevant research, because it provides subsidies for decision making and improvement of clinical practice, enabling, in a systematic way, the synthesis of knowledge of a particular content, in addition, it aims to promote the deepening of the investigated subject (Mendes, Silveira, \& Galvão, 2019).

Moreover, the integrative review (IR) follows important steps for its preparation, such as 1) Define the theme of the work and elaborate the guiding question; 2) Search and select the primary studies and delimit the inclusion and exclusion criteria; 3) Extract and organize the data from the primary studies; 4) Evaluate the primary studies with the use of tools; 5) Synthesize the results of the review and 6) Present the review (Mendes, Silveira \& Galvão, 2019). And as for the qualitative 
nature, Pereira et al., (2018) points out it is important for the researcher to be able to interpret with their opinions the studied phenomenon.

From this, the theme of the study was defined, and then the guiding question was formulated: What are the playful strategies in the scenario of pediatric hospitalization, and what are the benefits and importance in hospital humanization? Data collection was made by searching the Virtual Health Library (VHL) and its respective databases: Scielo, PubMed, Lilacs, Medline and BDENF. The descriptors "Child Health" AND "Play Therapy" were used, selected through the Descriptors in Health Sciences (DECS).

Subsequently, the PICo strategy was used, where the following were defined Population (P): hospitalized children; Intervention (I): use of play strategies in the hospital setting; Comparison (C): humanization of care for hospitalized children through play strategies; Outcomes $(\mathrm{O})$ : to promote a less traumatic recovery and allow tranquility in the hospital environment.

We included original articles available electronically, published from 2015 to 2021 and with linguistic parameters in English and Portuguese. Papers that did not address the subject of interest or did not answer the guiding question, publications with duplicity, theses, dissertations, and editorials were excluded. Based on the cross-referencing "Child Health" AND "Play Therapy", the review resulted in an initial sample of 246 articles. After using the inclusion criteria, only 54 articles remained, which were read individually and, at the end of the analysis, 17 articles were included in the study.

\section{Results and Discussion}

After reading all the full articles, a data collection tool was applied, containing the topics described in Table 1 (Souza, Silva \& Carvalho, 2010).

Table 1 - Description of the articles according to author, title, type of study, objective, and conclusion.

\begin{tabular}{|c|c|c|c|c|}
\hline Authors & Title & Type of study & Goals & Conclusion \\
\hline $\begin{array}{c}\text { Bezerra, Lima \& } \\
\text { Cavalcante (2021) }\end{array}$ & $\begin{array}{l}\text { Benefits of play therapy } \\
\text { in the chemotherapy } \\
\text { treatment of children } \\
\text { with leukemia: an } \\
\text { integrative review }\end{array}$ & $\begin{array}{l}\text { Integrative } \\
\text { review }\end{array}$ & $\begin{array}{l}\text { To demonstrate the benefits } \\
\text { of introducing play therapy } \\
\text { during chemotherapy } \\
\text { treatment in children with } \\
\text { leukemia. }\end{array}$ & $\begin{array}{l}\text { Playful activities help promote the } \\
\text { recovery process and make the hospital } \\
\text { environment lighter so that children can } \\
\text { progress in treatment; the junction } \\
\text { between care and play makes it more } \\
\text { humanized and induces better quality } \\
\text { care. }\end{array}$ \\
\hline $\begin{array}{l}\text { da Silva, de Souza } \\
\text { \& Teixeira (2019) }\end{array}$ & $\begin{array}{l}\text { The contributions of } \\
\text { play therapy for } \\
\text { hospitalized children }\end{array}$ & $\begin{array}{l}\text { Literature } \\
\text { review }\end{array}$ & $\begin{array}{l}\text { To investigate in the } \\
\text { literature the contributions } \\
\text { of play therapy in the } \\
\text { treatment of hospitalized } \\
\text { children }\end{array}$ & $\begin{array}{l}\text { Play therapy is extremely important in } \\
\text { the hospitalization process because it } \\
\text { reduces the psychological } \\
\text { illness, bringing new perspectives of care } \\
\text { to the child. }\end{array}$ \\
\hline $\begin{array}{c}\text { da Silva \& de } \\
\text { Oliveira Lima } \\
\text { (2018) }\end{array}$ & $\begin{array}{l}\text { The use of leading } \\
\text { activities in humanized } \\
\text { care for hospitalized } \\
\text { children: an integrative } \\
\text { review of the literature }\end{array}$ & $\begin{array}{l}\text { Integrative } \\
\text { review }\end{array}$ & $\begin{array}{l}\text { To identify the playful } \\
\text { activities used by health } \\
\text { professionals in the } \\
\text { humanized care of } \\
\text { hospitalized } \\
\text { humanized care of } \\
\text { hospitalized children }\end{array}$ & $\begin{array}{c}\text { Playful activities are essential for both } \\
\text { child development and the therapeutic } \\
\text { process, so it is considered by health } \\
\text { professionals as an important tool to } \\
\text { promote humanized care for hospitalized } \\
\text { children. }\end{array}$ \\
\hline $\begin{array}{l}\text { Dal'bosco et al., } \\
\text { (2019) }\end{array}$ & $\begin{array}{l}\text { Hospital Humanization } \\
\text { in Pediatrics: "Nurses } \\
\text { of Joy" Project }\end{array}$ & $\begin{array}{l}\text { Experience } \\
\text { Report }\end{array}$ & $\begin{array}{l}\text { To report on the relevance } \\
\text { of hospital humanization in } \\
\text { pediatrics through academic } \\
\text { practice in } \\
\text { play therapies. }\end{array}$ & $\begin{array}{l}\text { It was evidenced that initiatives such as } \\
\text { Enfermeiros da Alegria, which enables } \\
\text { the presence of clowns and children's } \\
\text { games in the hospital environment, } \\
\text { provide new meanings to care. }\end{array}$ \\
\hline
\end{tabular}




\begin{tabular}{|c|c|c|c|c|}
\hline $\begin{array}{l}\text { de Lima et al., } \\
\text { (2020) }\end{array}$ & $\begin{array}{l}\text { Prescription of the day: } \\
\text { play therapy }\end{array}$ & $\begin{array}{l}\text { Bibliographic } \\
\text { review }\end{array}$ & $\begin{array}{l}\text { To describe play therapy as } \\
\text { part of the treatment and } \\
\text { recovery of pediatric } \\
\text { patients, according to the } \\
\text { scientific publications in the } \\
\text { area }\end{array}$ & $\begin{array}{l}\text { Playful care in pediatrics aims to assist } \\
\text { the hospitalized child. } \\
\text { Nursing has a great role in this process, } \\
\text { promoting humanized care in all } \\
\text { dimensions, providing comfort and well- } \\
\text { being, using the dog, or the therapeutic } \\
\text { toy, and showing sensitivity. }\end{array}$ \\
\hline $\begin{array}{l}\text { de Melo Silva } \\
\text { et al., (2018) }\end{array}$ & $\begin{array}{l}\text { Perception of the } \\
\text { hospitalized child's } \\
\text { companion in relation } \\
\text { to therapeutic toys }\end{array}$ & Field study & $\begin{array}{l}\text { To identify the perception } \\
\text { of companions of } \\
\text { hospitalized children } \\
\text { regarding play activities. }\end{array}$ & $\begin{array}{l}\text { It is important that professionals working } \\
\text { in Pediatrics develop strategies for the } \\
\text { use of therapeutic play, improving the } \\
\text { assistance offered and, as a contribution, } \\
\text { providing more humane and qualified } \\
\text { care in the area. }\end{array}$ \\
\hline $\begin{array}{l}\text { de Oliveira Silva } \\
\text { et al., (2019) }\end{array}$ & $\begin{array}{l}\text { The use of play in the } \\
\text { pediatric hospitalization } \\
\text { scenario }\end{array}$ & $\begin{array}{l}\text { Exploratory } \\
\text { study }\end{array}$ & $\begin{array}{l}\text { To describe the perception } \\
\text { of the multiprofessional } \\
\text { team about the use of play } \\
\text { and the factors that interfere } \\
\text { in their practice in the } \\
\text { context of the care of } \\
\text { hospitalized children. }\end{array}$ & $\begin{array}{l}\text { the team faces difficulties related to } \\
\text { human and material resources, although } \\
\text { there are benefits; however, it invests so } \\
\text { that the child's integral care is mediated } \\
\text { in a humanized way, in the qualification } \\
\text { of the team and modification of the } \\
\text { practice of care in the hospital. }\end{array}$ \\
\hline $\begin{array}{l}\text { de Oliveira Soares } \\
\text { et al., (2018) }\end{array}$ & $\begin{array}{l}\text { University extension in } \\
\text { play therapy: steps } \\
\text { towards the humanized } \\
\text { sus that we want }\end{array}$ & $\begin{array}{l}\text { Experience } \\
\text { report }\end{array}$ & $\begin{array}{l}\text { To report the experience of } \\
\text { a horizontal and } \\
\text { multidisciplinary teaching } \\
\text { strategy and } \\
\text { multidisciplinary teaching } \\
\text { strategy in the Extension }\end{array}$ & $\begin{array}{l}\text { During the activities, the importance of } \\
\text { the institutionalization of the toy room by } \\
\text { the hospital management was evidenced, } \\
\text { as well as the need to establish in the } \\
\text { institution a nucleus for the } \\
\text { implementation of research and extension } \\
\text { projects that enable greater institutional } \\
\text { autonomy to establish new projects. }\end{array}$ \\
\hline $\begin{array}{c}\text { dos Santos et al., } \\
\text { (2017) }\end{array}$ & $\begin{array}{l}\text { Play therapy as a tool } \\
\text { for humanized nursing } \\
\text { care }\end{array}$ & $\begin{array}{l}\text { Integrative } \\
\text { review }\end{array}$ & $\begin{array}{l}\text { The objective was to } \\
\text { describe the treatment as } \\
\text { part of the treatment and } \\
\text { recovery of hospitalized } \\
\text { people. }\end{array}$ & $\begin{array}{l}\text { Treatment through play contributes to the } \\
\text { the well-being of hospitalized patients, } \\
\text { corroborating for a humanized care. }\end{array}$ \\
\hline Ducca (2020) & $\begin{array}{l}\text { The benefits of } \\
\text { ludotherapy and the use } \\
\text { of } \\
\text { therapeutic toy in } \\
\text { pediatric intensive } \\
\text { therapy units }\end{array}$ & $\begin{array}{l}\text { Bibliographic } \\
\text { review }\end{array}$ & $\begin{array}{l}\text { To identify the importance } \\
\text { of playfulness and } \\
\text { therapeutic play in assisting } \\
\text { children in the UTI } \\
\text { environment }\end{array}$ & $\begin{array}{l}\text { The use of playful activities as an } \\
\text { auxiliary therapeutic method in the care } \\
\text { of children in Pediatric Intensive Care } \\
\text { Units (UTIP) contributes to the } \\
\text { multidisciplinary team professionals' } \\
\text { ability to establish stress and tension } \\
\text { reduction, both for patients and family } \\
\text { members. } \\
\text { patients and family members }\end{array}$ \\
\hline $\begin{array}{l}\text { Lima \& Santos } \\
\quad(2015)\end{array}$ & $\begin{array}{l}\text { Play as a care strategy } \\
\text { for children with cancer }\end{array}$ & $\begin{array}{l}\text { Exploratory } \\
\text { descriptive } \\
\text { study }\end{array}$ & $\begin{array}{l}\text { To understand the infl uence } \\
\text { of play in the care process } \\
\text { as perceived by children } \\
\text { with cancer }\end{array}$ & $\begin{array}{c}\text { There are several activities at the hospital } \\
\text { that are considered play-related and, for } \\
\text { the children, they all benefi t their care } \\
\text { process. }\end{array}$ \\
\hline Morais (2020) & $\begin{array}{l}\text { The importance of play } \\
\text { therapy in the nursing } \\
\text { care of hospitalized } \\
\text { children }\end{array}$ & $\begin{array}{l}\text { Integrative } \\
\text { review }\end{array}$ & $\begin{array}{l}\text { Bringing out the importance } \\
\text { of play therapy in better } \\
\text { quality nursing care }\end{array}$ & $\begin{array}{l}\text { It was noticed that the practice of play is } \\
\text { easy to use and is indispensable for the } \\
\text { suffering of this pediatric patient is } \\
\text { alleviated or even eliminated. }\end{array}$ \\
\hline $\begin{array}{l}\text { Paixão, } \\
\text { Damasceno, \& } \\
\text { Silva (2016) }\end{array}$ & $\begin{array}{l}\text { Importance of Playful } \\
\text { Activities in Childhood } \\
\text { Oncology Therapy }\end{array}$ & $\begin{array}{l}\text { Bibliographic } \\
\text { review }\end{array}$ & $\begin{array}{l}\text { To discuss the importance } \\
\text { of play therapy in the care } \\
\text { of children hospitalized } \\
\text { with cancer, to identify the } \\
\text { types of play activities } \\
\text { developed during the } \\
\text { hospitalization process and } \\
\text { the benefits of play therapy } \\
\text { for children with cancer. }\end{array}$ & $\begin{array}{l}\text { It is essential to use play therapy } \\
\text { resources in the care environments of } \\
\text { children with cancer, because it favors, } \\
\text { besides fun, the expression of feelings } \\
\text { and emotions that the child goes through, } \\
\text { making it possible to personalize the } \\
\text { intervention. }\end{array}$ \\
\hline
\end{tabular}




\begin{tabular}{|c|c|c|c|c|}
\hline $\begin{array}{l}\text { Paula et al., } \\
\text { (2019) }\end{array}$ & $\begin{array}{l}\text { Playful strategies in the } \\
\text { nursing care of } \\
\text { hospitalized children }\end{array}$ & $\begin{array}{l}\text { Descriptive } \\
\text { study }\end{array}$ & $\begin{array}{l}\text { To analyze the use of play } \\
\text { strategies in hospitalized } \\
\text { child care from the } \\
\text { perspective of the Nursing } \\
\text { team }\end{array}$ & $\begin{array}{l}\text { It was evaluated that the limiting factors } \\
\text { need to be overcome in order to } \\
\text { guarantee integral care to hospitalized } \\
\text { children, considering that playing is a } \\
\text { legally guaranteed right, besides } \\
\text { contributing to a more pleasant recovery } \\
\text { and to full child development. }\end{array}$ \\
\hline $\begin{array}{l}\text { Santos, Santos \& } \\
\text { Silva (2017) }\end{array}$ & $\begin{array}{l}\text { Humanization in the } \\
\text { treatment of children } \\
\text { with cancer through } \\
\text { playful activities }\end{array}$ & $\begin{array}{l}\text { Integrative } \\
\text { review }\end{array}$ & $\begin{array}{l}\text { To evaluate the positive } \\
\text { impacts of playful activities } \\
\text { playful activities in the } \\
\text { treatment of children with } \\
\text { cancer }\end{array}$ & $\begin{array}{l}\text { It has been proven that playful activity is } \\
\text { effective } \\
\text { during treatment, as it results in good } \\
\text { prognosis for the children who have } \\
\text { access to it. }\end{array}$ \\
\hline Silva et al., (2018) & $\begin{array}{l}\text { The importance of play } \\
\text { in the context of } \\
\text { children's } \\
\text { hospitalization }\end{array}$ & $\begin{array}{l}\text { Integrative } \\
\text { review }\end{array}$ & $\begin{array}{l}\text { To analyze the importance } \\
\text { of play in the context of } \\
\text { child hospitalization. }\end{array}$ & $\begin{array}{l}\text { Playfulness is important in the context of } \\
\text { children's hospitalization, since it brings } \\
\text { benefits not only for the hospitalized } \\
\text { child, but also for the family and the } \\
\text { health team, besides enabling a more } \\
\text { humanized care. }\end{array}$ \\
\hline Silva et al., (2017) & $\begin{array}{l}\text { Angels of nursing: the } \\
\text { ludic as an instrument } \\
\text { of citizenship and } \\
\text { humanization in health }\end{array}$ & $\begin{array}{l}\text { Exploratory } \\
\text { study }\end{array}$ & $\begin{array}{l}\text { To identify the perception } \\
\text { of companions and/or tutors } \\
\text { regarding the importance of } \\
\text { Nursing Angels in the } \\
\text { treatment of } \\
\text { children/adolescents with } \\
\text { cancer. }\end{array}$ & $\begin{array}{l}\text { At the end of the study, the companions } \\
\text { demonstrated the positive impacts that } \\
\text { the playful activities developed by the } \\
\text { Nursing Angels bring to the pediatric } \\
\text { cancer treatment, which completely } \\
\text { changes the family and hospital } \\
\text { dynamics. }\end{array}$ \\
\hline
\end{tabular}

Source: Authors (2021).

From the thorough analysis of the selected articles, three categories were elaborated, being them: the strategies and resources that help with playfulness, the benefits of playful activities in the pediatric hospitalization scenario, and the importance of playful strategies in hospital humanization.

\subsection{Strategies and resources that aid ludicity}

Play therapy is an important tool to be used in the hospital environment, as it provides improvements in coping with diseases and treatments. According to the literature, there are several playful activities that help care for hospitalized children, such as puppets, clow theater, story reading, role-playing, clowns, paintings, toy library, and the therapeutic doll, which are the most commonly used by health professionals (da Silva, de Souza, \& Teixeira, 2019; Paula et al., 2019).

Regarding the hospital toy room, it consists of a specific place to use toys properly, therefore, the more toys there are in this space, the more distracted the child will be and the better their adaptation during hospitalization will be. Paixão, Damasceno and Silva (2016) mention some examples of toys that can be found in this environment, including dolls, assembly games and/or board games, balls, among other possibilities.

In the study by Melo Silva et al. (2018), a field research was conducted with ten caregivers about the use of the therapeutic toy (BT). The use of this instrument during the performance of procedures proved to be effective, and the companions reported a satisfaction and improvement in the emotional state of the children, where it was noticeable a greater willingness, better acceptance of the diet and there was improvement in communication and interaction between the child and the team. Corroborating the above study, Duca (2020) emphasizes that with the use of the BT it was noticed that children can come to understand the need for hospitalization and be able to experience this moment in a more peaceful way.

In addition to these playful activities, Lima and Santos (2015) emphasize the presence of the clown in this scenario of pediatric hospitalization, being an important participation for the reduction of traumas characteristic of hospitalization. It is noteworthy that this interaction between the child and the clown promotes stimuli, such as laughter and distraction, bringing 
benefits to the body, besides promoting relaxation, facilitating the interaction with other people, and establishing bonds and well-being to all those involved in the care process.

It is also observed some playful strategies that the team can use in the care of hospitalized children, such as the use of hospital materials, because children carefully observe the instruments used during procedures that are typical of the hospital environment, such as syringes and adhesive tape. In addition, another form of strategy are the group meetings that facilitate socialization, where it is possible to address issues such as healthy eating, personal hygiene, accident prevention, among others. Thus, it is important that professionals use this strategy to promote a playful scenario for hospitalized children (dos Santos et al., 2017; Paula et al., 2019).

\subsection{Benefits of playful activities in the pediatric hospitalization setting}

According to the studies, there are numerous playful activities that professionals can use in order to improve the child's interaction with the environment in which he/she is, in this case, the hospital. Therefore, it is important to highlight the benefits that playful strategies have in the care process, such as reducing pain, reducing depressive behavior, anxiety, and fear, and facilitating better communication between the child and the professional (Paixão, Damasceno, \& Silva, 2016).

In addition, the articles emphasize that the main feelings seen in children during playful activities were joy and contentment. From this, it is noted that this process minimizes tension and makes the hospital environment more pleasant, being a necessary and effective measure in the care of hospitalized children (Bezerra, Lima \& Cavalcante, 2021; Lima \& Santos, 2015).

It also emphasizes that playfulness influences not only children's emotions, but also the child's immunity (de Lima et al., 2020). According to the article by Silva et al., (2018), this resource contributes to the increase of the body's defense cells and, consequently, the child's well-being. For Dal'bosco et al., (2019) there is also distraction as a factor that helps in this process of care, since it allows the child to forget for a few moments the suffering and pain inherent to the disease and hospitalization.

Moreover, Paixão, Damasceno and Silva (2016) corroborate with the two authors cited above, they explain that laughter promoted by play has an analgesic effect, since it favors mood, increases immunity and decreases muscle tension and exhaustion, all through the limbic system and the release of neurotransmitters such as endorphin and serotonin. They also affirm that laughter promotes the exercise of breathing, considering that it acts as a myorelaxant, being essential to reduce tension, especially in moments of pain.

\subsection{Importance of ludic strategies in hospital humanization}

When hospitalized, patients have rights established by the National Humanization Policy (PNH), which promotes a closer relationship between health professionals and patients and between the hospital and society, aiming to improve the quality of services provided in the health unit. Thus, the use of playful activities in the hospital context emerges as a possibility to promote humanized care to hospitalized children, enabling proximity between the subjects and the formation of bonds between children, professionals, and family, and consequently, greater adherence to treatment (de Oliveira Soares et al., 2018; Morais, 2020).

As already mentioned, play helps to cope with hospitalization and provides humanization in the child's health care, through fun and relaxation, making them safer in the hospital environment, reducing stress and exposing their feelings with the purpose of the child making their choices and becoming more active (Santos, Santos, \& Silva, 2017).

In addition, according to Dal'bosco et al., (2019), health professionals need to strengthen bonds in order for the family to understand the process of hospitalization, the disease, and the necessary care for the child's recovery. Thus, it is believed that 
a well-informed family regarding the diagnosis and treatment enables more interaction with the team and easier adherence to treatment, thus providing humanization in child care.

Therefore, playful activities, when well employed in the pediatric hospitalization scenario, help in difficult moments for all those involved in the care process, in addition to playing an encouraging role, it also offers the child and family member the freedom to express their feelings (Paixão, Damasceno \& Silva, 2016). Moreover, in the study by Oliveira Silva et al., (2019) they state that:

Ludic is used mainly to reduce the suffering during the hospitalization process, both experienced by the children and their families. They arrive very weakened by the process of illness presented by the child, and this has repercussions on the entire family, not only on them. Play serves mainly as a way to make the hospital environment lighter (de Oliveira Silva et al., 2019, p. 3).

In this sense, it is evident that playful strategies are extremely important in the humanization of care for hospitalized children, because they reduce suffering and allow hospitalization to be less painful and traumatic. In addition, play therapy influences the ideal and humanized care, reducing the sequelae of the disease, awakening learning and social interaction (da Silva \& de Oliveira Lima, 2018; Bezerra, Lima \& Cavalcante, 2021).

\section{Conclusion}

It was concluded that playful strategies when implemented in the setting of pediatric hospitalization promote a less traumatic recovery, besides allowing for greater tranquility in the hospital environment. This junction between care and play therapy makes assistance more humanized; therefore, this resource must be implemented by the multiprofessional team so that hospitalized children can develop their abilities, such as self-confidence, cognition, psychomotor development, and socialaffective relationships.

Moreover, the use of playful strategies was pointed out by the studies as a communication resource that benefits not only the physical, emotional, and immunological aspects, but also the relationship between the child and the health professional, thus contributing to a greater trust in the therapy adopted and in the team. However, research on the application of play therapy in hospital settings is still limited. Thus, future studies are necessary to adapt the instruments to the characteristics of the hospital context, but it is noteworthy that the concepts and general lines of this methodological reference are perfectly applicable to the care of pediatric patients assisted in this space.

\section{References}

Bezerra, M. V. C., Lima, M. Á. B. D., \& Cavalcante, S. N. S. (2021). Benefícios da ludoterapia no tratamento quimioterápico de crianças com leucemias: uma revisão integrativa. Artigos publicados em Periódicos. http://openrit.grupotiradentes.com:8080/xmlui/handle/set/3925.

da Silva, E. M., de Souza, M. O., \& Teixeira, V. P. G. (2019). Contribuições da ludoterapia para crianças hospitalizadas. Gep News, 2 (2), 505-511.

da Silva, N. K. S., \& de Oliveira Lima, E. F. (2018). O uso das atividades lúdicas no atendimento humanizado as crianças hospitalizadas: uma revisão integrativa da literatura. Gep News, 2(3), 24-30.

Dal'Bosco, E. B., Barancelli, M. D. C., Gobatto, M., \& Schmidt, C. L. (2019). Humanização hospitalar na pediatria: projeto" enfermeiros da alegria. Journal of Nursing UFPE/Revista de Enfermagem UFPE, 13(4).

de Lima, D. A., de Almeida, B. T., Melo, K. C., \& Machado, M. L. (2020). Prescrição do dia: ludoterapia. Anais do Salão de Iniciação Cientifica Tecnológica ISSN-2358-8446, 1-5

de Melo Silva, S. R., Salustino dos Santos, M. C., Marinho da Silva, A., Ferreira, F. Â., Gouveia, M. T., Ferreira Guedes Rodrigues, W., \& Alcoforado dos Santos, R. E. (2018). Perception of the hospitalized child's companion in relation to therapeutic toys. Journal of Nursing UFPE/Revista de Enfermagem UFPE, 12(10). https://doi.org/10.5205/1981-8963-v12i10a236309p2703-2709-2018.

de Oliveira Silva, M. K. C., Costa Ferraz, L. C., Barbosa de Farias, M., Campos Januário, J. K., Santana Vieira, A. C., de Farias Moreira, R. T., \& Leite Lúcio, I. M. (2019). The use of play in the pediatric hospitalization scenario. Journal of Nursing UFPE/Revista de Enfermagem UFPE, 13. 
Research, Society and Development, v. 10, n. 5, e6210514652, 2021

(CC BY 4.0) | ISSN 2525-3409 | DOI: http://dx.doi.org/10.33448/rsd-v10i5.14652

https://doi.org/10.5205/1981-8963.2019.238585.

de Oliveira Soares, V. F., Cruz, K. R., da Rocha, M. L. B., de Barros Moreira, S. L., Bueno, L. D., \& Costa, M. C. L. (2018). Extensão Universitária em Ludoterapia: passos para o SUS Humanizado que Desejamos. Gep News, 2(2), 43-49.

dos Santos, S. S., da Silva Alves, A. B., Oliveira, J. C., Gomes, A., \& dos Santos Maia, L. F. (2017). A ludoterapia como ferramenta na assistência humanizada de enfermagem. Revista Recien-Revista Científica de Enfermagem, 7(21), 30-40. https://doi.org/10.24276/rrecien2358-3088.2017.7.21.30-40.

Ducca, P. D. S. (2020). Os benefícios da ludoterapia e o uso do brinquedo terapêutico em unidades de terapia intensiva pediátrica. Faculdade Sant'Ana em Revista, 4(2), 256-266.

Lima, K. Y. N. D., \& Santos, V. E. P. (2015). O lúdico como estratégia no cuidado à criança com câncer. Revista Gaúcha de Enfermagem, 36(2), 76-81. http://dx.doi.org/10.1590/1983-1447.2015.02.51514.

Mendes, K. D. S., Silveira, R. C. D. C. P., \& Galvão, C. M. (2019). Uso de gerenciador de referencias bibliográficas na seleção dos estudos primários em revisão integrativa. Texto \& Contexto-Enfermagem, 28. https://dx.doi.org/10.1590/1980-265X-TCE-2017-0204.

Morais, D. R. (2020). A importância da ludoterapia na assistência de enfermagem à criança hospitalizada. Artigos publicados em Periódicos. http://openrit.grupotiradentes.com:8080/xmlui/handle/set/3278.

Paixão, A. D. B., Damasceno, T. A. S., \& Silva, J. C. D. (2016). Importância das atividades lúdicas na terapia oncológica infantil. CuidArte, Enferm, $209-216$.

Paula, G. K. D., Góes, F. G. B., Silva, A. C. S. S. D., Moraes, J. R. M. M. D., Silva, L. F. D., \& Silva, M. D. A. (2019). Estratégias lúdicas no cuidado de enfermagem à criança hospitalizada. Rev. enferm. UFPE on line, 1-11. https://doi.org/10.5205/1981-8963.2019.238979.

Pereira, A. S., Shitsuka, D. M., Parreira, F. J., \& Shitsuka, R. (2018). Metodologia da pesquisa científica. UFSM.

Santos, C. S., Santos, M. O., \& Silva, J. D. O. M. (2017). Humanização no Tratamento de Crianças com Câncer Através das Atividades Lúdicas. In Congresso Internacional de Enfermagem, 1(1).

Silva, D. O. D., Gama, D. O. N., Pereira, R. B., \& Camarão, Y. P. H. C. (2018). A importância do lúdico no contexto da hospitalização infantil. Rev. enferm. UFPE online, 3484-3491.

Silva, L. S. R. D., Correia, N. D. S., Cordeiro, E. L., Silva, T. T. D., Costa, L. T. O. D., \& Maia, P. C. D. V. S. (2017). Anjos da enfermagem: o lúdico como instrumento de cidadania e humanização na saúde. Rev. enferm. UFPE on line, 2295-2301. 10.5205/reuol.10827-96111-1-ED.1106201706.

Souza, M. T. D., Silva, M. D. D., \& Carvalho, R. D. (2010). Revisão integrativa: o que é e como fazer. Einstein (São Paulo), 8(1), 102-106. http://dx.doi.org/10.1590/s1679-45082010rw1134. 